\title{
Universal Declaration Of Human Rights VS. Human Rights In Islam
}

\author{
Asma Manzoor, Saba Imran Ali \\ Women's Studies \\ University of Karachi \\ $\boldsymbol{d}$ \\ Muhammad Nadeemullah \\ Department of Social Work \\ University of Karachi
}

This is a declaration for mankind, a guidance and Instruction to those who fear God

(Al Qur'an, Al-Imran 3:138)

All human beings are born free and equal in dignity and rights. They are endowed with reason and conscience and should act towards one another in a spirit of brotherhood (UDHR, art.1)

\begin{abstract}
The Universal Declaration of Human Rights (UDHR) came into existence after World War II when the Nazi violence perpetrated upon the Jews came to light, the world community realized that the UN Charter was not sufficiently specific to protect human rights. In response, the Declaration was adopted by the United Nations General Assembly in Paris on December 10, 1948. General Assembly resolution 217 A (III) as a common standard of achievements for all peoples and all nations. It consists of 30 articles which cover a broad range including social, political, economic and religious rights. Though not legally binding, the UDHR is considered a foundational document in international human right laws. It has inspired the development of 50 human rights instruments around the world including international treaties, national constitutions, and regional human right laws.

Whereas Islamic law or Shari'ah, has been used in countries throughout the world for more than 1,400 years and remains the ideal legal system for more than a billion people worldwide. During the reign of the Ottoman Empire, the nations under its rule flourished in such diverse fields of medicine, education, social sciences and arts. While Shari'ah has been examined in great detail, religious scholars and groups for implementation in Islamic countries mostly completed the research. However, by comparing the rulings and methodology of Shari'ah to current systems around the world, it is possible to gain both a better understanding and also provides an alternative current system of laws.
\end{abstract}

$$
\begin{aligned}
& \text { تلخيص المقال }
\end{aligned}
$$

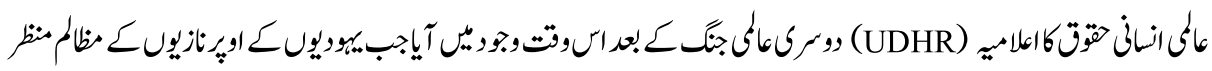

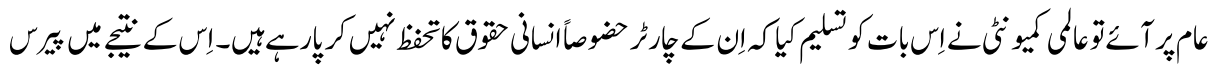

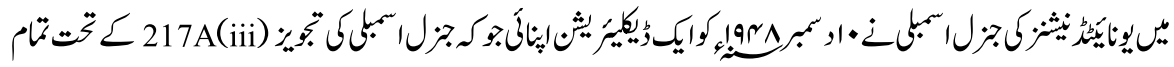




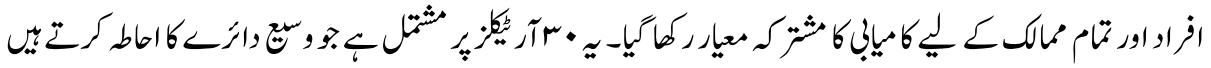

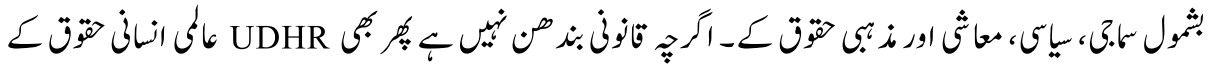

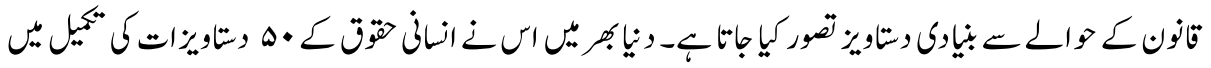

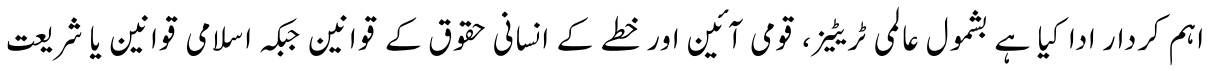

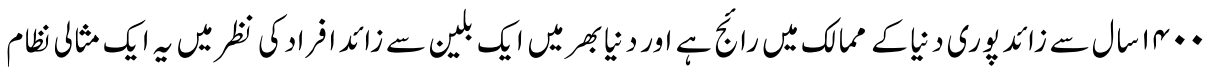

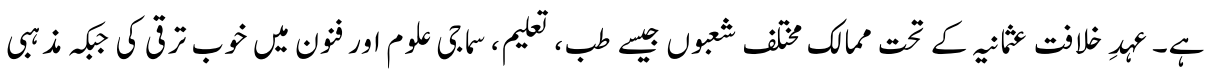

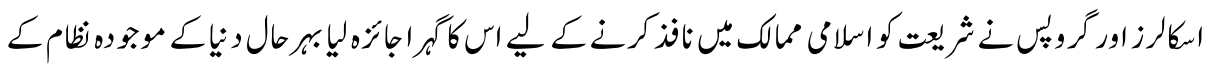

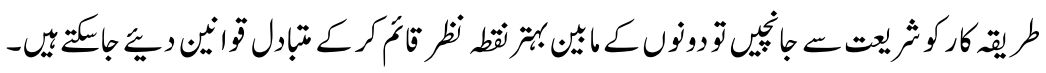

\section{Universal Declaration of Human Rights}

The International Bill of Human Rights consists of four major United Nations legal instruments, exist to define, to guarantee the protection of human rights: the Universal Declaration of Human Rights (UDHR, 1948), the International Covenant on Economic, Social and Cultural Rights (ICESCR, 1966), the International Covenant on Civil and Political Rights (ICCPR, 1966) and the Optional Protocol to the latter Covenant. The Declaration is a manifesto with primarily moral authority. The Covenant are treaties binding on the States which ratify them. Together they constitute four stages in the generation of the document the General Assembly has called the International Bill of Human Rights (United Nations, 1988).

Preparation of an International bill of Human Rights was a fundamental preoccupation of the United Nations. The Charter of the United Nations, agreed to in San Francisco in 1945, in seven different articles declared United Nations support for human rights and set up a Human Rights Commission. In the first session in January 1946, the General Assembly called for the Commission to work towards "the formulation of an international bill of rights". When the Commission on Human Rights began its work in February 1947, this item was its first priority. (United Nations, 1996).

On 10 December 1948 the General Assembly adopted the Universal Declaration of Human Rights by a vote of 48 States voted in favour of the Declaration, none against, with eight abstentions. In a statement following the voting, the President of the General Assembly pointed out that adoption of the Declaration was "a remarkable achievement, a step forward in the great evolutionary process" (UN, 1988).

The UDHR is the basic international statement of the inalienable and inviolable rights adopted and proclaimed by the General Assembly as a common standard of achievement for all members of the human family and all nations, to the end that every individual and every organ of society, keeping this Declaration constantly in mind, shall strive by teaching and education to promote respect for these rights and freedoms and by progressive measures, national and international, to secure their universal and effective 
recognition and observance, both among, the peoples of Member States themselves and among the peoples of territories under their jurisdiction (UN, 1996).

The Declaration consists of a preamble and 30 articles, setting forth the human rights and fundamental freedoms to which all men and women, everywhere in the world, are entitled, without any discrimination. Recognition of the inherent dignity and of the equal and inalienable rights of all members of the human family is the foundation of freedom, justice, and peace in the world, where as disregard and contempt for human rights have resulted in barbarous acts which have outraged the conscience of mankind, and the advent of a world in which human beings shall enjoy freedom of speech and belief and freedom from fear and want has been proclaimed as the highest aspiration of the common people, it is essential, if man is not to be compelled to have recourse, as a last resort, to rebellion against tyranny and oppression, that human rights should be protected by the rule of law, it is essential to promote the development of friendly relations between nations, the peoples of the UN have the Charter reaffirmed their faith in fundamental human rights, in the dignity and worth of the human person and in the equal rights of men and women and have determined to promote social progress and better standards of life in larger freedom, whereas Member states have pledged themselves to achieve, in cooperation with the $\mathrm{UN}$, the promotion of universal respect for and observance of human rights and fundamental freedoms (UN,1988).

Article 1 of the declaration lays down the philosophy of the Declaration that All human beings are born free and equal in dignity and rights. They are endowed with reason and conscience and should act towards one another in a spirit of brotherhood. Therefore the article defines the basic assumptions of the Declaration that liberty and equality is the man's birthright and cannot be alienated: and that, because man is a rational and moral being, he is different from other living beings on earth and therefore entitled to certain rights and freedoms which other living beings do not enjoy.

Article 2 sets out the basic principle of equality and non discrimination as regards the enjoyment of human rights and fundamental freedoms, forbids distinction of any kind, such as race, colour, sex, language, religion, political or other opinion, national or social origin, property, birth or other status.

Article 3 is the first keystone of the Declaration, proclaims the right to life, liberty and security of person $-\mathrm{a}$ right essential to the enjoyment of all other rights. This article introduces articles 4 to 21 , in which other civil and political rights are set out, including the right to freedom from slavery or servitude; freedom from torture and cruel, inhuman or degrading treatment or punishment; the right to recognition everywhere as a person before the law; the right to an effective judicial remedy; freedom from arbitrary arrest, detention or exile; the right to a fair trial and public hearing by an independent and impartial tribunal; the right to be presumed innocent until proved guilty; freedom from arbitrary interference with privacy, family, home or correspondence; freedom of 
movement and residence; the right of asylum; the right to a nationality; the right to marry and to found a family; the right to own property; freedom of thought, conscience and religion; freedom of opinion and expression; the right to peaceful assembly and association; and the right to take part in the government of one's country and to equal access to public service in one's country.

Article 22 is the second keystone of the Declaration which introduces articles 23 to 27, in which economic, social and cultural rights -the rights to which everyone is entitled as a member of society -are set out. The article characterizes these rights as indispensable for human dignity and the free development of personality, and indicates that they are to be realized through national effort and international cooperation. At the same time, it points out the limitations of realization, the extent of which depends on the resources of each State. The economic, social and cultural rights recognized in articles 22 to 27 include the right to social security; the right to work; the right to equal pay for equal work; the right to rest and leisure; the right to a standard of living adequate for health and well-being; the right to education; and the right to participate in the cultural life of the community.

The concluding articles, articles 28 to 30 , recognize that everyone is entitled to a social and international order in which the human rights and fundamental freedoms set forth in the Declaration may be fully realized, and stress the duties and responsibilities which each individual owes to his community. Article 29 states that in the exercise of his rights and freedoms, everyone shall be subject only to such limitations as are determined by law solely for the purpose of securing due recognition and respect for the rights and freedoms of others and of meeting the just requirements of morality, public order and the general welfare in a democratic society. It includes that in no case may human rights and fundamental freedoms be exercised contrary to the purposes and principles of the United Nations. Article 30 emphasizes that no State, group or person may claim any right, under the Declaration, to engage in any activity or to perform any act aimed at the destruction of any of the rights and freedoms set forth in the Declaration (UN, 1996).

\section{Facts Regarding Islamic Law}

Islam gave to mankind an ideal code of human rights 1,400 years ago. These rights aim to confer honour and dignity on mankind and eliminating exploitation, oppression and injustice. Human rights in Islam are firmly rooted in the belief that Allah and Allah alone, is the Law Giver and the Source of all human rights. Due to their Divine origin, no ruler, government or authority can curtail or violate in any way the human rights conferred by Allah nor can they be surrendered.

Human rights in Islam are an integral part of the overall Islamic order and it is obligatory on all Muslim states and all parts of the society to implement them in spirit within the framework of that order. It is unfortunate that human rights are being trampled upon with impunity in many countries of the world, including some Muslim countries. Such 
violations are a matter of serious concern and are arousing the conscience of more and more people throughout the world.

Islam is a religion based on the faith in the one God and the eternal life to come after which every human being will be accountable for all of his/her deeds in the world life, and the moral values emphasized in all messages of Allah and agreed upon by the human common sense (Osman, 2006). Islamic Shari'ah law is merely a part of the religion which supports the moral values through law: Allah enjoins justice, and magnanimity, and generosity towards one's kinsfolk; and He forbids all that is shameful and all that runs counter to reason, as well as aggression (The Holy Qur'an, 16: 90, 1946). Shari'ah represents a comprehensive legal system, not only a penal law, it secures the human rights and dignity in its moral and material dimensions, as well as it establishes the mutual rights and obligations of the ruled and the rulers, indicating that the rulers are entrusted with authority from among the people by the people (The Holy Qur'an 4: 59, 1946). Shari'ah guards justice in all its dimensions, including socio-economic justice which requires that ones earnings must be through some provided matter or efforts as states that "squander not your wealth among yourselves in vanity, expect it be a trade by mutual consent" (The Holy Qur'an 4 : 29), and states certain view spending for the poor and the needy and the society as a whole since individual earnings benefit from divine gifts and collective natural and human resources (The Holy Qur'an 57 : 7, 70 : 24-25, 9: 103).

In order to properly understand the concept of human rights under the Islamic law, it is helpful to have a basic grasp of the concepts of Islamic law or Shari'ah. The general public and many scholars have several preconceived notions about Islamic law. Some contemporary scholars fail to recognize Islamic law as an equal to other systems of law such as English Common Law and European Civil Law. Few scholars have even tried to place Islamic Law into the Civil Law traditions (Madkoar).

Islamic law or Shari'ah in not merely a penal law, and the penal law is not merely the fixed punishments for certain serious crimes against the society, the punishments which are called in Arabic "Hudud", a word which means "bounds that should not be transgressed" in general not only the fixed legal punishment for certain crimes: "These are the limits ordained by Allah; do not, then, transgress them, for they who transgress the limits ordained by Allah-it is they who are evidence" (The Holy Qur'an 2: 229), " and one who transgresses the bounds set by Allah does indeed wrong against his/her own self" (The Holy Qur'an 65:1). These crimes with fixed punishments are: theft (The Qur'an 5:38), adultery (The Qur'an 24:2), slander (The Qur'an 24:4), and committing assaults against life and property (The Qur'an 5:23). Besides, "Shari'ah" states retribution "Qisas" as a punishment for crimes that destroys the human life or injures the human body (The Qur'an 2:178-9,194). Punishments of other crimes or even similar crimes which lack any identifying and qualifying conditions for the crime is authorized to 
the human discretion and judgment through a fair penal legislation made by the jurists (Osman).

Thus, "Hudud" as a term used for limited fixed punishments for certain crimes in addition to the retribution for assaults on human body, represent the only part of the Islamic penal law which is indicated in the Qur'an, the Sunnah of the Prophet. Other crimes and their punishments have to be provided through human legislative with all the requirements for a fair law. Furthermore, "Shari'ah" is not restricted to penal law whether its origin is divine or human, since it covers branches of law, public - as constitutional, administrative and or criminal, or private as civil, commercial, and labour, in addition to socio-economic laws which may stand between the two categories and probably may combine the characteristics of both. "Shari'ah" in all its areas has been always developed and expanded and supplemented - not only interpreted - through different times and places by the human legislation. The jurists have developed general legal rules "Qawa'id" based on the principle of the Qur'an and Sunnah. These general rules of Islamic Justice are applied to respond to any emerging need or case, such as analogy "Qiyas", preference "Istihsan", and the consideration of significant public interests which are not indicated specifically in the Qur'an and Sunnah "al-masalih al-mursala". Voluminous works in Islamic jurisprudence include pioneering juristic additions to the body of "Shari 'ah", responding to the particular needs of a given place and time as considered by a concerned jurist (Osman).

Further, as it has been previously indicated, Islam is a religion whose essence is the faith and the moral values, while "Shari'ah" is merely a legal support for the moral behavior of the individual and the society.

\section{Sources of Islamic Practices and Traditions}

Before addressing the issue of human rights in Islam, it is of vital importance to clarify that the Islamic practice and traditions like other major religious practices and traditions does not consist of, or derive from, a single source. Most Muslims if questioned about its sources are likely to refer to more than one of the following: the Qur'an or the Book of Revelation; the Sunnah or the practical traditions of the Prophet Muhammad; Hadith or the oral sayings attributed to the Prophet Muhammad; Fiqh (Jurisprudence) or Madahib (Schools of Law); and the Shari'ah or code of law which regulates the diverse aspects of a Muslim's life. While these "sources" have contributed to what is cumulatively referred to as "the Islamic tradition", they are not identical or considered to be of equal weight. Of all the sources of the Islamic tradition, undoubtedly, the most important is the Qur'an which is regarded by Muslims in general, as the primary, and most authoritative, source of normative Islam (Hassan).

To many Muslims the Qur'an is the Magna Carta of human rights and a large part of its concern is to free human beings from the bondage of traditionalism, authoritarianism 
(religious, political, economic, or any other), tribalism, racism, sexism, slavery or anything else that prohibits or inhibits human beings from actualizing the Qur'anic vision of human destiny embodied in the classic proclamation (Hassan): "Towards Allah is thy limit" (The Holy Qur'an, 53: 42).

The Qur'an's affirmation of fundamental rights which all human beings ought to possess because they are so deeply rooted in our humanness that their denial or violation is tantamount to a negation or degradation of that which makes us human(Hassan).. From the perspective of the Qur'an, these rights came into existence when we did; they were created, as we were, by Allah in order that our human potential could be actualized (Hassan). Rights created or given by Allah cannot be abolished by any ruler or human organization. Eternal and absolute, they ought to be exercised since everything that God does is for "a just purpose" (The Holy Qur'an, 15: 85, 16: 3, 44: 39, 45: 22, 46: 3).

\section{Human Rights in Islam}

According to the Qur'an, dignity of the children of Adam is a divine bestowal, which is to be secured by all means, including the law and the state authorities, and is to be defended by all forces: We have conferred dignity on the children of Adam, and borne them over land and sea, and provided for them sustenance out of the good things of life, and favored them far above most of our Creations. (The Holy Qur'an 17:70). What distinguish humans from other creatures are mainly their intellect and their free will to choose between doing good and evil. To fulfill a human potential, all obstacles and pressures must be removed from the way, and all means should be secured to maintain and develop our humanity. The dignity bestowed on humans in the Qur'an must be defended. It is the individual, social and universal responsibility of Muslims to guard human rights because oppression is an obstruction of Allah's will in His creation: As for that life in the life to come, We grant it (only) to those who do not seek to exalt themselves on earth, nor yet to spread malevolence: for the future belongs to the Godconscious. (The Holy Qur'an 28:83).

It is the individual, social, and universal responsibility of Muslims, according to their faith, to protect the human merits and virtues of all the children of Adam, whatever their differences may be. Defending the human rights of any human being is a religious duty for a Muslim, who believes that any oppression is an obstruction of Allah's will and plan in His creation (Osman). Moreover, a Muslim believes that God has created all mankind equal as human beings, and no one can claim superiority in this respect, whatever his/her ethnicity, family, wealth or gender may be. The Qur'an teaches: O humanity! Be conscious of your Lord, who has created you out of one living entity, and out of it created its mate, and out of the two spread abroad a multitude of men and women. And remain conscious of Allah, in whose name you demand your rights from one another (and before Him you will be accountable), and of these ties of kinship. Verily, Allah is ever watchful over you. (The Holy Qur'an 4:1). 
O humanity! Behold, we have created you all out of a male and a female, and have created you into nations and tribes, so that you might come to know one another. Verily, the noblest of you in the sight of God is the one who is most deeply conscious of Him. Behold, God is All-Knowing, All-Aware (The Holy Qur'an 49:13).

The only One who is above all humans is their Creator and Lord: And there is nothing that could be compared with Him (The Holy Qur'an 112:4). At the inception of the belief in one Allah is the belief in the equality of all human beings, since those who believe in one Allah believe that all human beings are created by the one Creator. Thus, deeply rooted in the conscience of believers is the duty to maintain human rights and to practice equality in the process (Osman). Any discrimination against any individual or group about their basic rights as members of humanity is a challenge to the faith of believers, since for any human to claim superiority based on origin or power is contradictory to the belief in the One Ultimate Supreme Being: ...the All-Highest, who creates everything, and thereupon forms in accordance with what it is meant to be. He cannot be questioned for his acts, but they will be questioned (for theirs) (The Holy Qur'an 21:23).

Qur'an states that those who will attain happiness in the life to come, as it has been mentioned before, are those who don't seek to exalt themselves on earth, nor yet to spread malevolence; for the future belongs to the God-conscious (The Holy Qur'an 7:157). Thus, the Qur'an repeatedly emphasizes human rights and justice, and condemns injustice, aggression and oppression. It highlights the message of the Prophet Muhammad PBUH: --enjoins upon them the doing of what is right and forbids the doing of what is wrong, and makes lawful to them the good things of life and forbids the bad things, and lifts from them their burdens and the shackles that were upon them (The Holy Qur'an 7:157).

Any discrimination between men and women in rights or responsibilities is forbidden according to the divine justice- the same as any other discrimination: And their Lord does answer them: I shall not lose sight of the work of any of you who works in My way, be it man or woman ... (The Holy Qur'an 3:195).

And as for the believers, both men and women - they are incharge of and responsible for one another and form together one body, they all enjoin the doing of what is right and forbid the doing of what is wrong, and keep up their prayers, and render the purifying social dues, and pay heed unto God and the conveyer of His Message (The Holy Qur'an 9:71).

Divine justice can never be for Muslims only. It secures the rights of all human beings, whatever their beliefs may be. It is especially protective of the rights of belief and practicing one's belief... "Let there be no coercion in matters of faith" (The Holy Qur'an 2:256). Defending all houses of worship is legitimate and urged: ...for if Allah had not enabled people to defend themselves against one another, all monasteries and churches 
and synagogues and mosques in all of which Allah's name is abundantly exalted - would surely have been destroyed, and Allah will most certainly support one who supports His cause....(The Holy Qur'an 22:40).

Muslims are taught by the Qur'an to build their relations with others on kindness, while the minimum obligation which should be strictly observed is justice (The Holy Qur'an 60:8). They should always have in mind that no hostility stays permanently, and that if they follow Allah's guidance, their behavior may turn an enemy into a close friend: Yet Allah may develop affection between you and those of them you felt were enemies, for Allah is All Powerful, Much Forgiving and Most Gracious (The Holy Qur'an 60:7).

Islam secures the human rights even for those who may violate the human rights of others, since two wrongs do not make one right. A violation should be stopped instantly, but the rights of the violator as a human being should be secured. Islamic law aims to fight the crime in its origin, not just to inflict punishment. Islamic penal law is enforced in order to prevent the sources of violation and transgression without social justice and public education for all. It is required that every possible effort be made to educate and rehabilitate an offender, not to destroy him/her. And finally, the Prophet PBUH states that a mistaken decision in acquitting a guilty person is better than a mistaken decision of punishing an innocent one. (From an authentic tradition of the Prophet PBUH repeated by Ibn Ali Shayba, al Tirmidhi, al-Hakim and al-Bayhaqi in al-Sunan, on the authority of Aisha) (Osman).

Islamic civil and commercial law prohibits illegitimate and exploitative gains while protecting the principle which has been earned legitimately and legally before usurious additions: ....and give up all outstanding gains from usury...for if you do not, then know that you are at war with God and the Conveyer of His Message. But if you repent, you shall be entitled to your principals. You will do no wrong and neither will you be wronged.

The Islamic law of war requires an open declaration of the start of military operations, and limits fighting to the combatants only. As soon as the aggression itself is stopped and the aggressor submits to justice, justice should be maintained in relation to both parties equally: ....but then, if one of the two groups goes on aggressing against the other, fight against the aggressors until they revert to Allah's commandment; and if they revert make peace between them (both parties) with justice, and deal equitably [with them], for verily, God loves those who act equitably (The Holy Qur'an 49:9).

Any of the enemy's army who asks for protection or shelter should be granted it, and may be returned to his camp if he so requests: And if any of those who ascribe divinity to aught beside God seeks your protection, grant him protection, so that he might be able to hear the word of Allah from you; and thereupon convey him to a place where he can feel secure (The Holy Qur'an 9:6). 
The wounded and deserters from the enemy's army should not be attacked, but should be cared for until they are cured or repatriated. Human rights as described by the divine message in Qur'an and Sunnah were considered by the Muslim jurists to be the Avery goal of Shari'ah. The jurists condensed Islamic law, as mentioned before, into the securing and developing human personality in five main areas: life, family, mind, faith, and property. The human rights covered by these five areas include the collective rights of groups and peoples as well as the rights of individuals; political and social rights have their place side by side. A collective effort to defend the powerless and the oppressed against a powerful oppressor is an essential Islamic obligation. Every right is considered a responsibility and an obligation (Osman). In addition to human rights being considered a collective responsibility of the Muslim Ummah and the authorities, every holder of a right must also struggle for him/her self to obtain, maintain and enjoy this right.

An accurate balance has to be maintained between basic spiritual and moral development and education on one side, and the protection of values by the law and the state on the other. A balance should be maintained between rights and duties. Based on faith in Allah, the Islamic perspective on human rights is comprehensive and deep. When a Muslim fighter was asked by the Sassanian leader, Rustum, about the cause that he was fighting for, he simply answered, Allah has sent us to transport human beings from the worship of one another to the worshipping of One Allah, from a narrow life to a wide world, and from the dominant injustice under other beliefs to the justice of Islam. (al-Tabari, in his reports about the battle of al-Qadisiyyah in $17 \mathrm{AH} / 637 \mathrm{CE}$ ). This was the message of Islam in early times: a universal liberation and establishment of justice and maintenance of human rights. It is thus to maintain, develop and spread such an understanding of the divine message in our times.

\section{References}

Hassan, Riffat, Are Human Rights Compatible with Islam? The Issues of the Rights of Women in Muslim Communities, Retrieved on January 27, 2010, http://www.religiousconsultation.org/hassan2.htm\#sources

Madkoar, Mohammed Salam, Human Rights from an Islamic World view: An outline of Hudud, Ta'zir \& Qisas, Retrieved on January 12, 2010, http://www.islamawareness.net/Shari'ah/sh article002.html.

Osman, Dr. Fathi (2006) "Facts about Islamic Law" Lecture at Omar ibn al Khattab Foundation, Los Angeles, Retrieved on January 26, 2010, http://www.usc.edu/schools/college/crcc/engagement/issues/

The Holy Qur'an Surrah 53: 42, Surrah $17: 10$, Surrah $28: 83$, Surrah $4: 1$, Surrah 49 : 13, Surrah $112: 4$, Surrah $21: 23$, Surrah $7: 157$, Surrah $3: 195$, Surrah $9: 71$, Surrah 2 : 256, Surrah $22: 40$, Surrah $60: 7,8$, Surrah $49:$ 9, Surrah $9: 6$. 
The Holy Qur'an Surrah 15: 85, Surrah 16: 3, Surrah 44 : 39, Surrah 45: 22, Surrah 46 : 3, Surrah $16: 90$, Surrah 4: 29,59, Surrah $57:$ 7, $70: 24-25,9: 103$, Surrah 2 :229, Surrah $65: 1$, Surrah 5 : 38, Surrah $24: 2$, 4, Surrah 5 : 23, Surrah 2 : 178179, 194.

United Nations (1988) The International Bill of Human Rights, New York, United Nations.

United Nations (1996) Fact Sheet No.2 (Rev.1), The International Bill of Human Rights, Geneva, United Nations.

Asma Manzoor is Lecturer at Centre of Excellence for Women's Studies, University of Karachi.

Saba Imran Ali is Lecturer at Centre of Excellence for Women's Studies, University of Karachi.

Muhammad Nadeemullah is Lecturer at Department of Social Work, University of Karachi. 